\title{
VIBRATION ANALYSIS OF A TORPEDO BATTERY TRAY USING FEA
}

\author{
P. Ravinder Reddy ${ }^{1}$, P.Shashikanth Reddy ${ }^{2}$, K.Vineeth Kumar Reddy ${ }^{3}$ \\ ${ }^{1}$ Professor \& Head, MED, Chaitanya Bharathi Institute of Technology, Hyderabad 75, AP, India \\ ${ }^{2}$ CAE Analyst, Concurrent Analysis Pvt. Ltd, Hyderabad-28, AP, India \\ ${ }^{3} P G$ Student, MED, Chaitanya Bharathi Institute of Technology, Hyderabad-75, AP, India
}

\begin{abstract}
In this work the performance evaluation of vibration analysis on the battery tray is carried out and checked for sustainability under severe operating conditions using finite element analysis. The battery tray consists of cells and electrical wiring which is used for the torpedo's battery backup, which requires stability under sailing. The battery tray is modeled with Pro Engineer software. This model in IGES format is imported to HYPERMESH version VI1 for development of converged mesh. The meshed file is then imported to ANSYS V14 and the analysis is performed. The shock and vibration on the tray is performed with the input parameters such as g loads, frequency and acceleration/amplitude's then static, modal and harmonic analysis results obtained from the ANSYS FEA software is compared with that of experimental predictions.
\end{abstract}

Keywords: Battery tray, modal frequencies, frequency response, dynamic stability

\section{INTRODUCTION}

The torpedo is a self-propelled weapon with an explosive warhead, launched above or below the water surface, propelled underwater towards a target, and designed to detonate either on contact with its target or in proximity to it. The battery which is the driving force for this torpedo is induced with many vibrations as the torpedo moves with very high speeds. In order to keep the battery configuration safe in its position the tray must withstand to those induced vibrations. The battery tray which is a structural member made of aluminum needs to withstand high loads under severe conditions. As there are no numerical simulations carried out for this typical component it is very essential to perform the simulation and to compare the simulated results with experimental results. Further this simulation helps in finding out the behavior of this structure subjected to higher loads and other analyses. The experimental tests can be termed as environmental tests. The vibration test is undertaken to determine the suitability of the battery to withstand severities of vibration. This test shall be carried out on one complete battery/group of cells in non-activated condition in case of primary batteries and charged condition in case of secondary batteries. After the vibration test, the battery and the structure shall be examined for any physical damage or deformation. In this work an attempt has been made on numerical simulation on the battery tray with different loads. To perform static analysis and to find out the deformation and stresses for each acceleration load in each axis respectively. To determine the first 10 natural frequencies and respective mode shapes of the battery tray using modal analysis component system in ANSYS and then to perform harmonic analysis on the battery tray for the frequency range obtained in modal analysis and to determine the frequency response of the component in each of the 3 axes respectively.

\section{LITERATURE REVIEW}

A.A. Vasilopoulosa and D.E. Beskos [1] studied Seismic design of plane steel frames using advanced methods of analysis. Carlos E.N. Mazzillia, César T. Sanchesa, Odulpho G.P. Baracho Netoa, Marian Wiercigrochb and Marko Keberb [2] studied 'Non-linear modal analysis for beams subjected to axial loads'. The dynamical responses were compared in terms of time histories, phase portraits and mode shapes. Maurinia, , M. Porfirib, and J. Pougeta [3]studied 'Numerical methods for modal analysis of stepped piezoelectric beams'. Hong Hee Yooa, Jung Eun Chob, and Jintai Chungc [4] studied Modal analysis of cantilever beams undergoing rotation and its shape and shape optimization. Krawczuk, Ostachowicz and Zak [5] had studied Modal analysis of composite beam that is cracked and unidirectional. With a single transverse fatigue crack, a model along with an algorithm were presented to create the characteristic matrices of a composite beam. Siu Lai Chana [6] studied 'Vibration and modal analysis of steel frames with semi-rigid connections'. In practical design, frames are assumed to be connected either by rigid or pinned joints. Strictly speaking, all joints are semi-rigid, so this assumption does not normally represent the actual behaviour of a realistic steel frame. Wei Gao [7] studied 'Interval natural frequency and mode shape analysis for truss structures with interval parameters'. Y. L. Xu, and W. S. Zhang [8] studied 'Modal analysis and seismic response of steel frames with connection dampers'. In between the connection of end plate and column flange or between the angle and member flange, dissipation materials may be placed in order to minimize dynamic response of a steel frame of bolted connections. Vibration problems regarding uniform/variable thickness plates resting on Pasternak foundation have attracted research workers due to their important role in foundation engineering and the availability of various numerical techniques and computational facilities [9-13]. 


\section{MODELING AND MESHING OF BATTERY}

\section{TRAY}

\subsection{Modeling of the Tray}

The tray is modeled using Pro ENGINEER V5.0. In order to model the tray sheet metal option is used for modeling sheets and punches and part modeling option for modeling bars, rivets, threads, strips, and other solid parts. All these parts are assembled to form the complete component. The unexploded view of the model can be seen in the figure 1 .

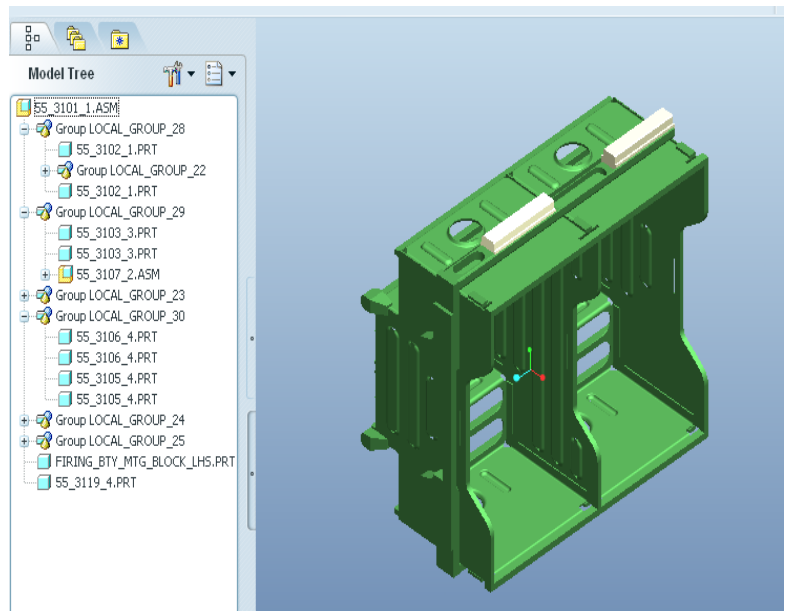

Fig-1: Final model of battery tray

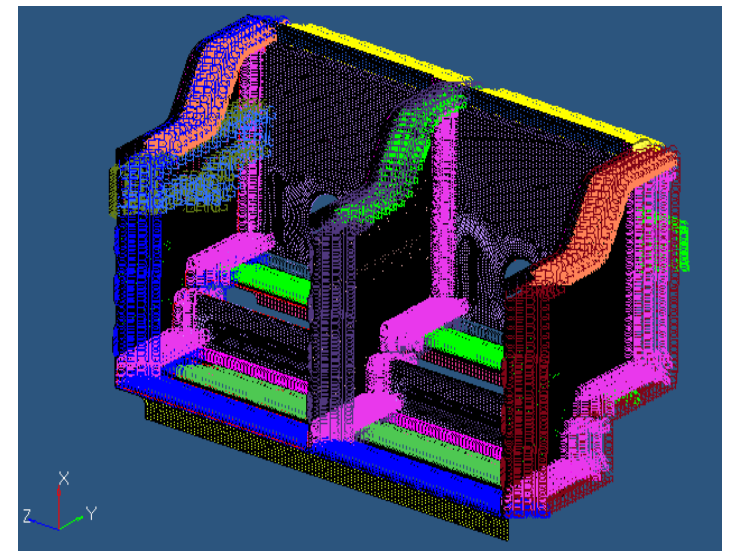

Fig-2: Converged mesh of tray with rigid connections

The material considered is aluminum and Teflon, the various properties are represented in table1.

Table-1: Material properties

\begin{tabular}{|l|l|l|}
\hline $\begin{array}{l}\text { Material } \\
\text { properties }\end{array}$ & $\begin{array}{l}\text { Aluminum } \\
\text { alloy(IS733) }\end{array}$ & Teflon \\
\hline Density, kg/m & 2700 & 2200 \\
\hline $\begin{array}{l}\text { Young's } \\
\text { Modulus, MPa }\end{array}$ & 70000 & 500 \\
\hline Poissons ratio & 0.35 & 0.43 \\
\hline
\end{tabular}

\subsection{Meshing of the Tray}

Meshing of all the parts of the assembly has been done using hyperworks 10 as the model geometry is very complex. The mesh is carried on by extracting the mid surface for each part and then meshing those parts individually by hiding other parts. 2-D mesh option is used to mesh the middle surfaces and then the density is given in order to extend the mesh up to the thickness of the component then the solid mesh is obtained. The meshed component can be seen in the figure 2. The total number of elements after meshing with the element size as $4 \mathrm{~mm}$ are 2,16,138 and the total number of nodes in the mesh is 4,81,411. A cell load of $0.0121 \mathrm{MPa}$ on $\mathrm{x}$-axis, $\mathrm{y}$ axis and $\mathrm{z}$-axis with $\mathrm{g}$ loads of 0 to $50 \mathrm{~g}$ in each axis is applied on the tray as a static loads. In the case of harmonic analysis a pressure of $0.0121 \mathrm{MPa}$ in $\mathrm{X}$-direction the frequency range of 0 to 680 in each $\operatorname{axis}(\mathrm{X}, \mathrm{Y} \& \mathrm{Z})$ is applied.

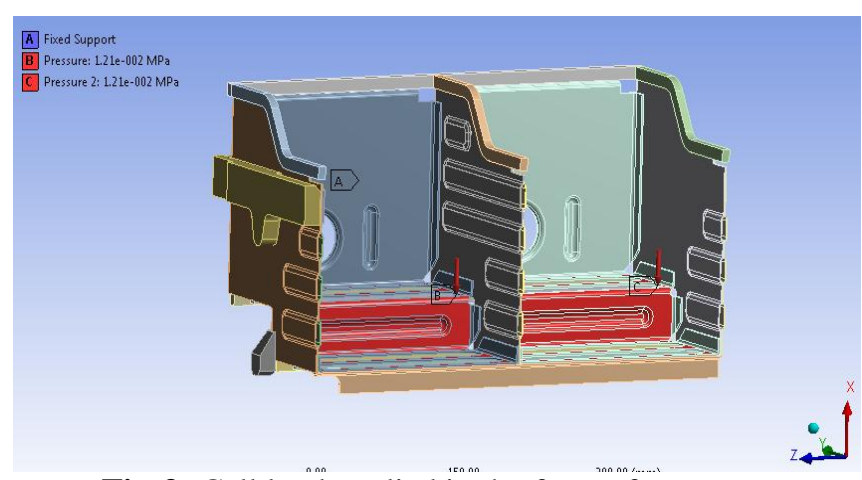

Fig-3: Cell load applied in the form of pressure

\section{RESULTS AND DISCUSSIONS}

Table2 shows that as the ' $\mathrm{g}$ ' loads applied in $\mathrm{x}$-axis increase the total deformation, equivalent stress and normal stress are increasing linearly.

Table -2: The deformation and stresses induced in the tray when the load is in $\mathrm{x}$-axis

\begin{tabular}{|l|l|l|l|l|}
\hline $\begin{array}{l}\text { 'g' } \\
\text { loads }\end{array}$ & $\begin{array}{l}\text { Total } \\
\text { deformation, } \\
\mathrm{mm}\end{array}$ & $\begin{array}{l}\text { Equivalent } \\
\text { stress, MPa }\end{array}$ & $\begin{array}{l}\text { Normal } \\
\text { stress, } \\
\mathrm{MPa}\end{array}$ & $\begin{array}{l}\text { Factor of } \\
\text { safety }\end{array}$ \\
\hline $2 \mathrm{~g}$ & 0.024263 & 17.964 & 15.412 & 17.84 \\
\hline $10 \mathrm{~g}$ & 0.028162 & 19.499 & 16.714 & 16.4 \\
\hline $20 \mathrm{~g}$ & 0.033041 & 21.418 & 18.343 & 12.839 \\
\hline $30 \mathrm{~g}$ & 0.038135 & 23.336 & 19.971 & 11.7843 \\
\hline $40 \mathrm{~g}$ & 0.043453 & 25.334 & 21.666 & 10.85 \\
\hline $50 \mathrm{~g}$ & 0.048355 & 25.174 & 23.227 & 10.9 \\
\hline
\end{tabular}

In the same way the static analysis is performed by applying the ' $\mathrm{g}$ ' loads in Y-axis and the results obtained are summarized in the table3. From the table 3 it is clear that as the acceleration loads are increased in Y-direction the deformation and stresses are also increasing. Now the static analysis is performed by applying the ' $\mathrm{g}$ ' loads in Z-axis and the results obtained are summarized in the table 4 . The summarized results in table 4 clearly show that as the acceleration loads are increased the deformations and stresses are increasing linearly in Z-axis. The modal analysis 
is performed on the battery tray then first 10 natural frequencies predicted are $220.51 \mathrm{~Hz}, 333.25 \mathrm{~Hz}, 377.33 \mathrm{~Hz}$, $447.59 \mathrm{~Hz}, 530.76 \mathrm{~Hz}, 611.09 \mathrm{~Hz}, 633.71 \mathrm{~Hz}, 634.33 \mathrm{~Hz}$, $651.81 \mathrm{~Hz}$, and $664.3 \mathrm{~Hz}$ and the corresponding first six mode shapes obtained are shown in figure4.

Table -3: The deformation and stresses induced in the tray when the load is in Y-axis

\begin{tabular}{|l|l|l|l|l|}
\hline $\begin{array}{l}\text { 'g' } \\
\text { loads }\end{array}$ & $\begin{array}{l}\text { Total } \\
\text { deformation, } \\
\mathrm{mm}\end{array}$ & $\begin{array}{l}\text { Equivalen } \\
\mathrm{t} \text { stress, } \\
\mathrm{MPa}\end{array}$ & $\begin{array}{l}\text { Normal } \\
\text { stress, } \\
\mathrm{MPa}\end{array}$ & $\begin{array}{l}\text { Factor of } \\
\text { safety }\end{array}$ \\
\hline $2 \mathrm{~g}$ & 0.024052 & 17.96 & 15.384 & 15.311 \\
\hline $10 \mathrm{~g}$ & 0.035115 & 19.481 & 16.576 & 14.11 \\
\hline $20 \mathrm{~g}$ & 0.057108 & 21.382 & 18.066 & 12.86 \\
\hline $30 \mathrm{~g}$ & 0.07927 & 23.284 & 19.568 & 11.81 \\
\hline $40 \mathrm{~g}$ & 0.10151 & 25.185 & 21.154 & 10.91 \\
\hline $50 \mathrm{~g}$ & 0.12376 & 27.086 & 22.739 & 10.1 \\
\hline
\end{tabular}

Table- 4: The deformation and stresses induced in the tray when the load is in Z-axis

\begin{tabular}{|l|l|l|l|l|}
\hline $\mathrm{g}$ loads & $\begin{array}{l}\text { Total } \\
\text { deformation, } \\
\mathrm{mm}\end{array}$ & $\begin{array}{l}\text { Equivalent } \\
\text { stress, MPa }\end{array}$ & $\begin{array}{l}\text { Normal } \\
\text { stress, } \\
\mathrm{MPa}\end{array}$ & $\begin{array}{l}\text { Factor } \\
\text { of } \\
\text { safety }\end{array}$ \\
\hline $2 \mathrm{~g}$ & 0.025887 & 17.897 & 15.105 & 15.36 \\
\hline $10 \mathrm{~g}$ & 0.1015 & 23.499 & 17.461 & 11.702 \\
\hline $20 \mathrm{~g}$ & 0.20677 & 46.154 & 24.267 & 5.958 \\
\hline $30 \mathrm{~g}$ & 0.31204 & 69.087 & 33.897 & 3.98 \\
\hline $40 \mathrm{~g}$ & 0.41731 & 92.02 & 44.664 & 2.988 \\
\hline $50 \mathrm{~g}$ & 0.51768 & 116.39 & 44.465 & 2.362 \\
\hline
\end{tabular}

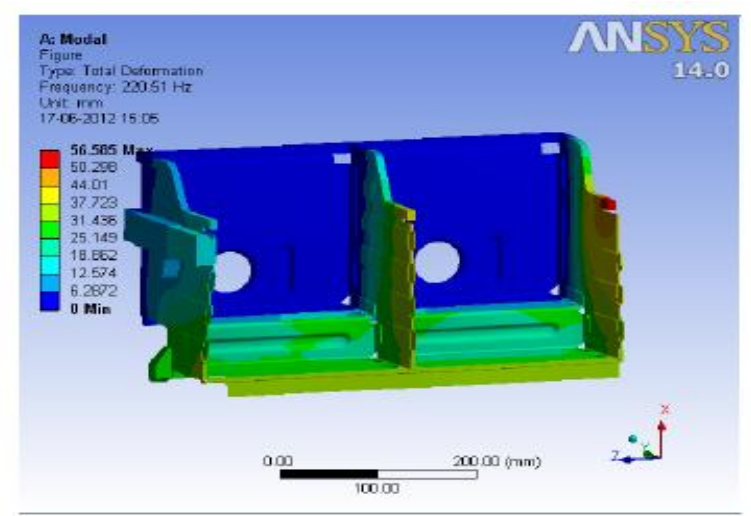

(a) $1^{\text {st }}$ mode at frequency $220.51 \mathrm{~Hz}$

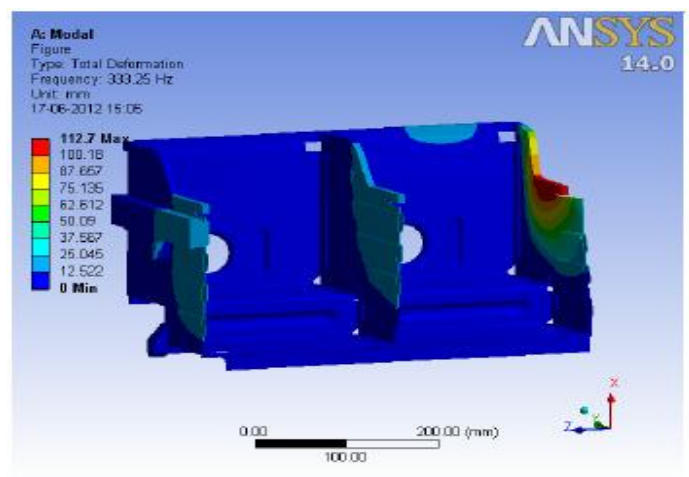

(b) $2^{\text {nd }}$ mode at frequency $333.25 \mathrm{~Hz}$

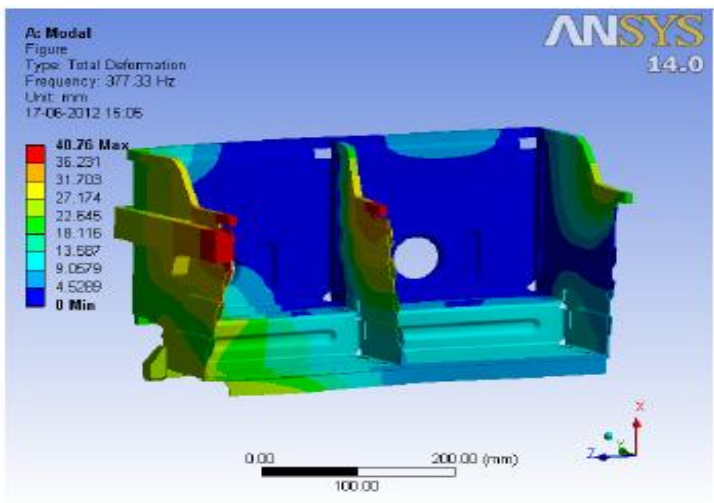

(c) $3^{\text {rd }}$ mode at frequency $377.33 \mathrm{~Hz}$

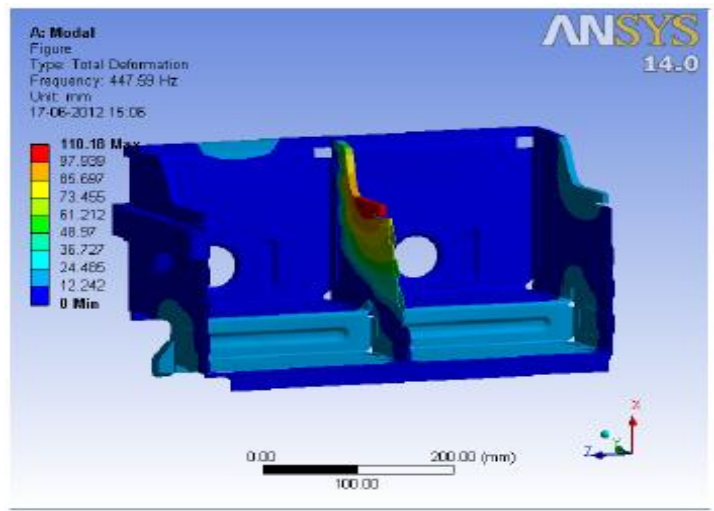

(d) $4^{\text {th }}$ mode at frequency $447.59 \mathrm{~Hz}$

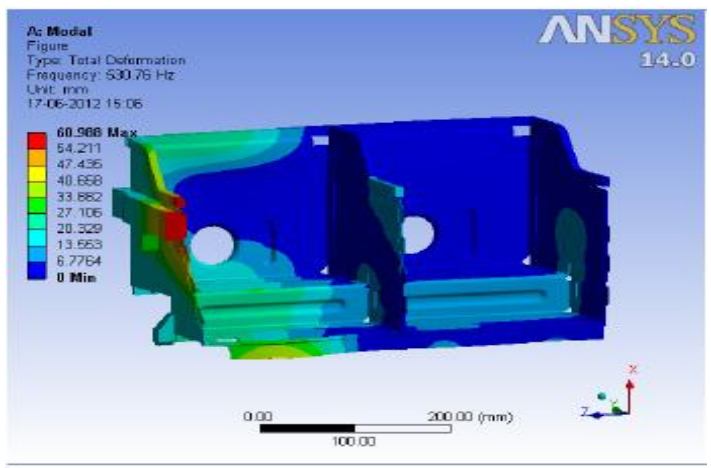

(e) $5^{\text {th }}$ Mode at frequency $530.76 \mathrm{~Hz}$

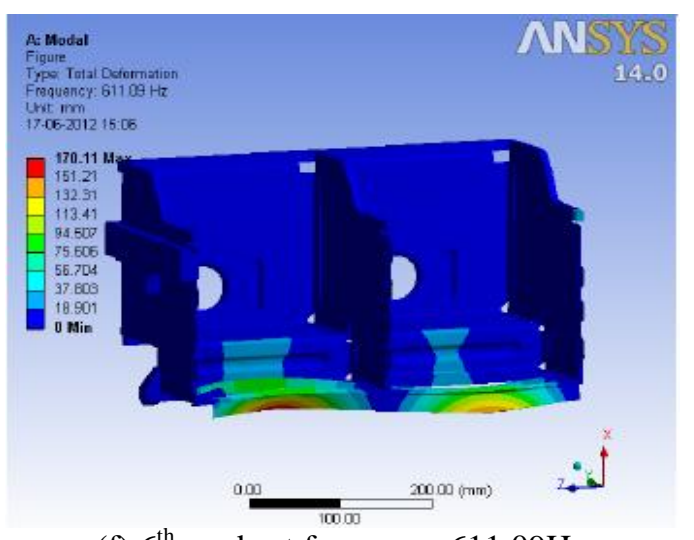

(f) $6^{\text {th }}$ mode at frequency $611.09 \mathrm{~Hz}$

Fig-4: First six mode shapes of battery tray 
Harmonic analysis is performed by giving the frequency range and other input parameters in each axis respectively. Figure5 clearly shows that as the frequency increases amplitude gradually increases till $630 \mathrm{~Hz}$ and comes down from $630 \mathrm{~Hz}$ to $680 \mathrm{~Hz}$. The maximum amplitude occurs at a frequency of $630 \mathrm{~Hz}$. It is clear that the phase angle of the tray is constant i.e., 180 degrees till $500 \mathrm{~Hz}$ and varies from $500 \mathrm{~Hz}$ to $680 \mathrm{~Hz}$.
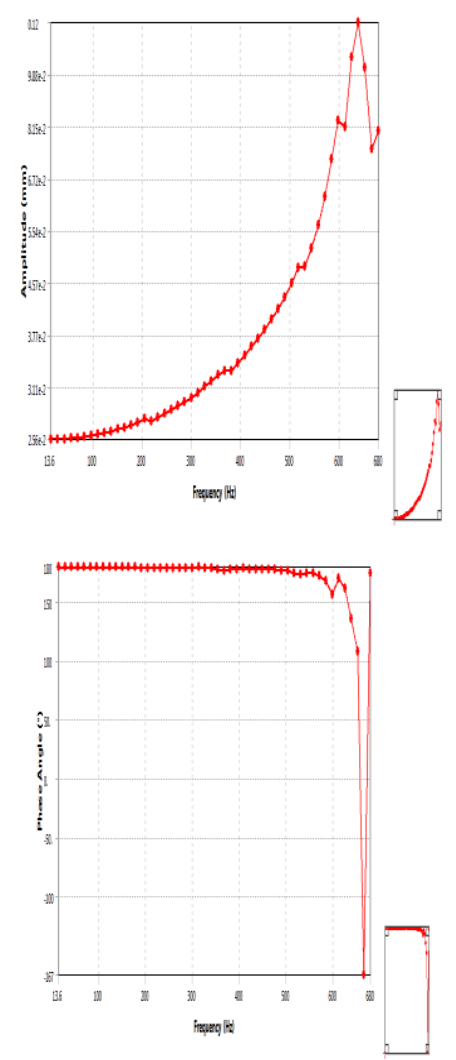

Fig-5: Amplitude and phase with increase in frequency of the tray in $\mathrm{x}$-axis
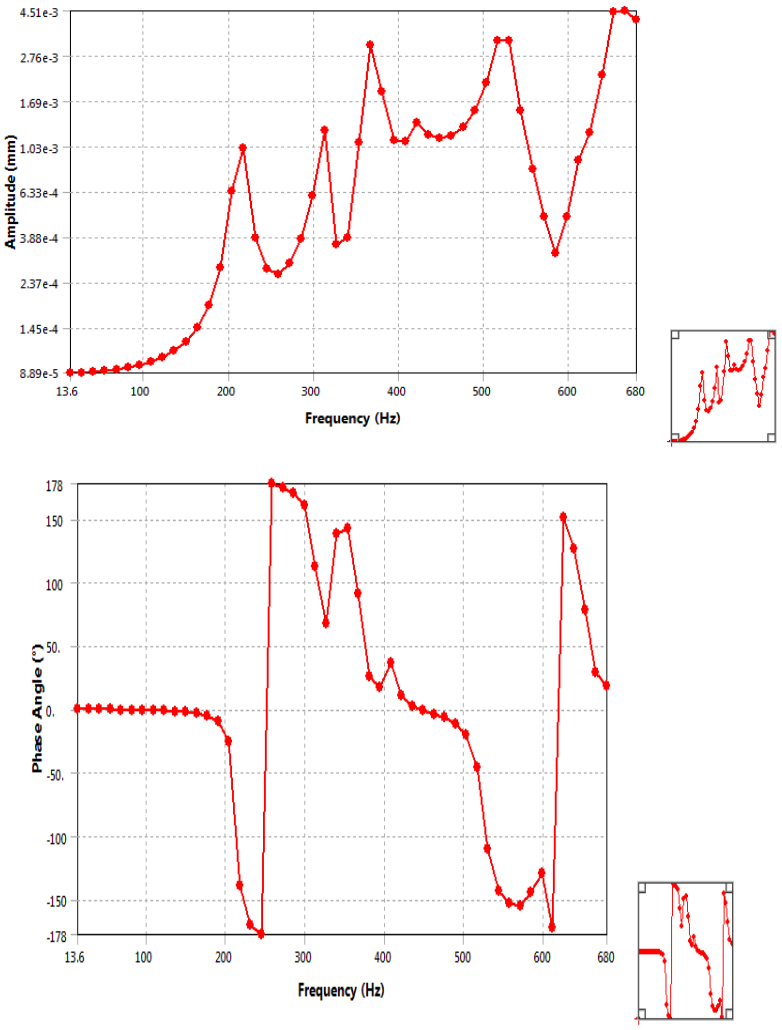

Fig-6: Amplitude and phase with increase in frequency of the tray in y-axis

The figure6 shows the sinusoidal variation of amplitude with respect to frequency in $\mathrm{Y}$-axis. The maximum amplitude was obtained at $660 \mathrm{~Hz}$ in $\mathrm{Y}$-axis and value of maximum amplitude is less compared with the maximum amplitude obtained in $\mathrm{X}$-axis. Ihe continuous variation of phase angle with frequency in $\mathrm{Y}$-axis and maximum phase angle 180degrees occurred at frequency of $255 \mathrm{~Hz}$. The frequency response of the tray in $\mathrm{Z}$-axis varies continuously as shown in figure 7 and the maximum amplitude of $1.17 \mathrm{e}-$ $2 \mathrm{~mm}$ is obtained at $220 \mathrm{~Hz}$. The maximum phase angle of 180 degrees is obtained at $300 \mathrm{~Hz}$ and $400 \mathrm{~Hz}$ respectively and the variation of phase angle is continuous for this orientation.

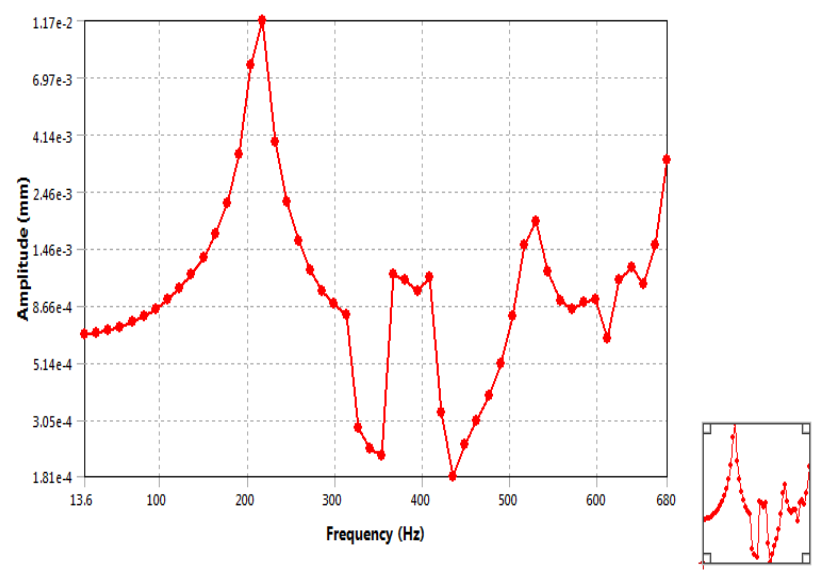




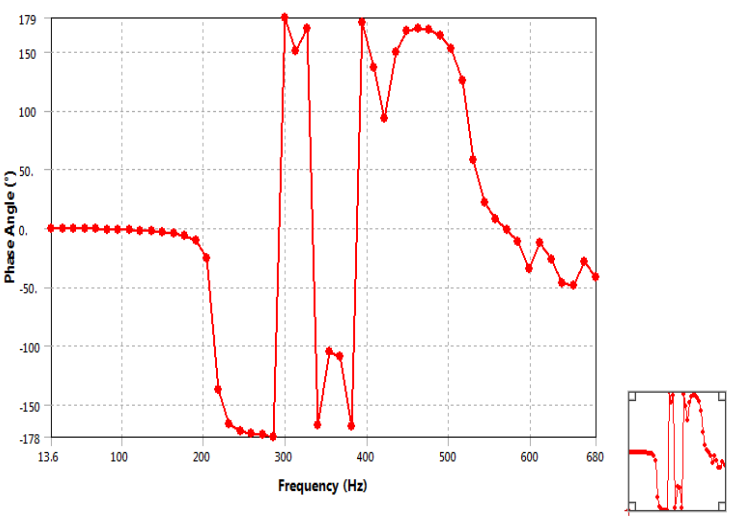

Fig-7: Amplitude and phase with increase in frequency of the tray in z-axis

As the selected face has been supported with guide rail on the side and stiffeners on the top the maximum amplitude occurs at highest frequency in all the three axis. This shows that the faces which have supports and stiffeners can withstand to maximum frequencies. The maximum amplitude for this face alon $\mathrm{x}, \mathrm{y}$ and $\mathrm{z}$-axis are $0.00108 \mathrm{~mm}$, $0.0329 \mathrm{~mm}$ and $0.0254 \mathrm{~mm}$ as shown in figure 8 .

\section{SHOCK TEST}

The test setup consists of shock machine and fixture on which the battery unit will be mounted, figure 9 shows the battery unit mounted on the test setup for shock test. After calibrating the shock machine the unit was fastened to the fixture using clamps and using tie rods in longitudinal axis and requires number of shocks were given as per specification in each axis. Various functional and environmental tests are performed on the battery unit to ensure that it withstands the required specifications and severities. The acceleration loads given for the shock test are from $20 \mathrm{~g}$ to $40 \mathrm{~g}$. The deformations and stresses measured for each acceleration load in each of the three axis given in table 5 to table 7.
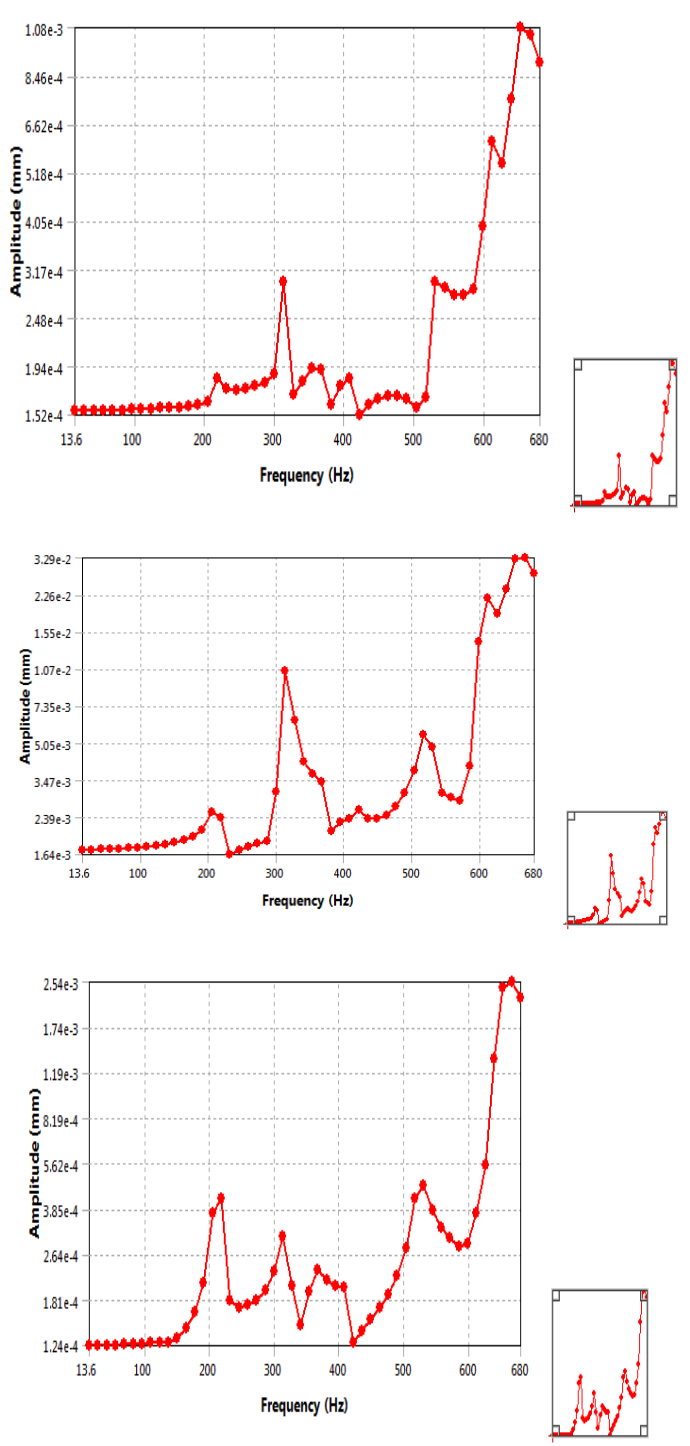

Fig-8: Amplitude in $\mathrm{x}, \mathrm{y}$ and $\mathrm{z}$ direction with frequency

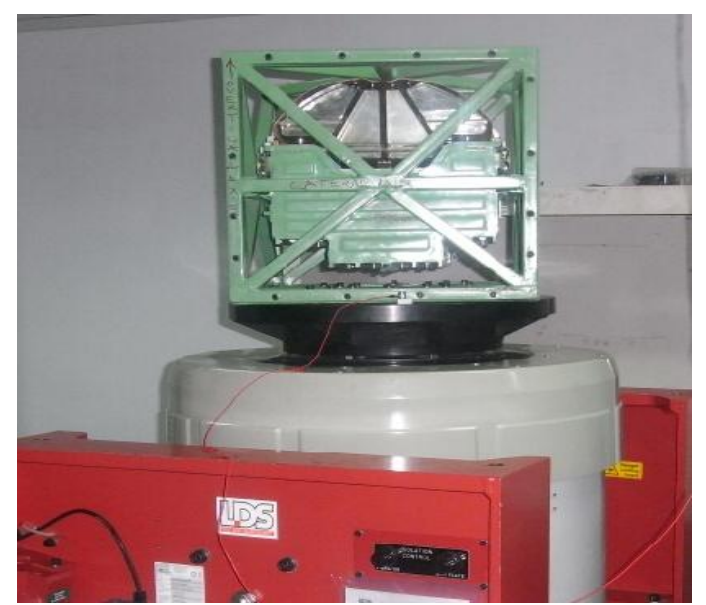

Fig-9: Battery unit mounted on the test setup

The maximum total deformation obtained in experimental and simulation results for different ' $\mathrm{g}$ ' loads in each axis are compared as shown in the table8. 
Table- 5: Deformations and stresses obtained in $\mathrm{x}$-axis shock loading

\begin{tabular}{|l|l|l|l|}
\hline $\begin{array}{l}\text { 'g' } \\
\text { loads }\end{array}$ & $\begin{array}{l}\text { Total } \\
\text { deformation, mm }\end{array}$ & $\begin{array}{l}\text { Normal stress, } \\
\text { MPa }\end{array}$ & $\begin{array}{l}\text { Equivalent } \\
\text { stress, MPa }\end{array}$ \\
\hline $20 \mathrm{~g}$ & 0.031 & 17.3 & 19.8 \\
\hline $30 \mathrm{~g}$ & 0.036 & 18.1 & 22.7 \\
\hline $40 \mathrm{~g}$ & 0.041 & 19.8 & 23.8 \\
\hline
\end{tabular}

Table -6: Deformations and stresses obtained in y-axis shock loading

\begin{tabular}{|l|l|l|l|}
\hline $\begin{array}{l}\text { 'g' } \\
\text { loads }\end{array}$ & $\begin{array}{l}\text { Total deformation, } \\
\mathrm{mm}\end{array}$ & $\begin{array}{l}\text { Equivalent } \\
\text { stress, MPa }\end{array}$ & $\begin{array}{l}\text { Normal } \\
\text { stress, MPa }\end{array}$ \\
\hline $20 \mathrm{~g}$ & 0.051 & 20 & 17.4 \\
\hline $30 \mathrm{~g}$ & 0.072 & 21.4 & 18 \\
\hline $40 \mathrm{~g}$ & 0.099 & 23.6 & 19.9 \\
\hline
\end{tabular}

Table -7: Deformations and stresses obtained in z-axis shock loading

\begin{tabular}{|l|l|l|l|}
\hline $\begin{array}{l}\text { 'g' } \\
\text { loads }\end{array}$ & $\begin{array}{l}\text { Total } \\
\text { deformation, mm }\end{array}$ & $\begin{array}{l}\text { Equivalent } \\
\text { stress, MPa }\end{array}$ & $\begin{array}{l}\text { Normal } \\
\text { stress, MPa }\end{array}$ \\
\hline $20 \mathrm{~g}$ & 0.199 & 42.3 & 22.9 \\
\hline $30 \mathrm{~g}$ & 0.303 & 64.8 & 32.3 \\
\hline $40 \mathrm{~g}$ & 0.398 & 88.9 & 41.68 \\
\hline
\end{tabular}

Table- 8: Comparison of deformations

\begin{tabular}{|c|c|c|c|}
\hline \multirow[t]{2}{*}{ 'g' loads } & \multicolumn{2}{|c|}{ Max total deformation, $\mathrm{mm}$} & \multirow{2}{*}{$\begin{array}{l}\text { Percentage } \\
\text { difference }\end{array}$} \\
\hline & Experimental & FEA & \\
\hline $20 \mathrm{~g}$ (x-axis) & 0.031 & 0.033041 & 6.2 \\
\hline $30 \mathrm{~g}(\mathrm{x}$-axis $)$ & 0.036 & 0.038135 & 5.53 \\
\hline $40 \mathrm{~g}(\mathrm{x}$-axis $)$ & 0.041 & 0.043453 & 5.6 \\
\hline $20 \mathrm{~g}(\mathrm{y}$-axis $)$ & 0.051 & 0.057108 & 10 \\
\hline $30 \mathrm{~g}(\mathrm{y}$-axis $)$ & 0.072 & 0.07927 & 9.2 \\
\hline $40 \mathrm{~g}(\mathrm{y}$-axis $)$ & 0.099 & 0.10151 & 2.5 \\
\hline $20 \mathrm{~g}(\mathrm{z}$-axis $)$ & 0.199 & 0.20677 & 4 \\
\hline $30 \mathrm{~g}$ (z-axis) & 0.303 & 0.31204 & 3 \\
\hline $40 \mathrm{~g}(\mathrm{z}$-axis $)$ & 0.398 & 0.41731 & 4.7 \\
\hline
\end{tabular}

Table -9: Comparison of experimental and numerical results of max normal stress

\begin{tabular}{|l|l|l|l|}
\hline \multirow{2}{*}{$\begin{array}{l}\text { 'g' } \\
\text { loads }\end{array}$} & \multicolumn{2}{|l|}{ Maximum normal stress, MPa } & Percentage \\
\cline { 2 - 3 } & $\begin{array}{l}\text { Experimental } \\
\text { analysis }\end{array}$ & $\begin{array}{l}\text { Finite } \\
\text { element } \\
\text { analysis }\end{array}$ & \\
\hline $20 \mathrm{~g}($ x-axis $)$ & 17.38 & 18.343 & 5.3 \\
\hline $30 \mathrm{~g}($ x-axis $)$ & 18.1 & 19.971 & 9.3 \\
\hline $40 \mathrm{~g}($ x-axis $)$ & 19.8 & 21.666 & 9.5 \\
\hline $20 \mathrm{~g}($ y-axis $)$ & 17.4 & 18.066 & 3.58 \\
\hline $30 \mathrm{~g}($ y-axis $)$ & 18 & 19.568 & 8 \\
\hline $40 \mathrm{~g}($ y-axis $)$ & 19.9 & 21.154 & 5.8 \\
\hline $20 \mathrm{~g}(\mathrm{z}$-axis $)$ & 22.9 & 24.267 & 5.6 \\
\hline $30 \mathrm{~g}(\mathrm{z}$-axis $)$ & 32.3 & 33.897 & 4.7 \\
\hline $40 \mathrm{~g}(\mathrm{z}$-axis $)$ & 41.68 & 44.664 & 6.6 \\
\hline
\end{tabular}

Table -10: Comparison of experimental and Finite Element Analysis (FEA) results of max equivalent stress

\begin{tabular}{|l|l|l|l|}
\hline \multirow{2}{*}{ 'g' loads } & \multicolumn{2}{|l|}{ Max. Equivalent stress, MPa } & \multirow{2}{*}{$\begin{array}{l}\text { Percentage } \\
\text { variation }\end{array}$} \\
\cline { 2 - 3 } & Experimental & FEA & 7.3 \\
\hline $20 \mathrm{~g}$ (x-axis $)$ & 19.8 & 21.418 & 3.2 \\
\hline $30 \mathrm{~g}$ (x-axis $)$ & 22.7 & 23.336 & 6.4 \\
\hline $40 \mathrm{~g}$ (x-axis $)$ & 23.8 & 25.334 & 7.2 \\
\hline $20 \mathrm{~g}($ y-axis $)$ & 20 & 21.382 & 8 \\
\hline $30 \mathrm{~g}($ y-axis $)$ & 21.4 & 23.284 & 6.3 \\
\hline $40 \mathrm{~g}($ y-axis $)$ & 23.6 & 25.185 & 6.2 \\
\hline $20 \mathrm{~g}(\mathrm{z}$-axis $)$ & 42.3 & 46.154 & 3.3 \\
\hline $30 \mathrm{~g}$ (z-axis $)$ & 64.8 & 69.087 & \\
\hline $40 \mathrm{~g}(\mathrm{z}-$-axis $)$ & 88.9 & 92.02 & \\
\hline
\end{tabular}

From table 8 it is noted that maximum deformation in $\mathrm{x}, \mathrm{y}$ and $\mathrm{z}$ axes is obtained at a load of $40 \mathrm{~g}$ in both experimental and finite element analysis. The comparison shows a difference of $6-7 \%$ on an average. The normal stresses obtained for experimental and FEA results for loads of $20 \mathrm{~g}$, $30 \mathrm{~g}$ and $40 \mathrm{~g}$ in $\mathrm{x}, \mathrm{y}$ and $\mathrm{z}$ axis are tabulated in table 9. The comparison of experimental and FEA results in table 9 shows $5-7 \%$ of average variation in the results of normal stresses in each axis. The maximum normal stresses in each axis are obtained for a load of $40 \mathrm{~g}$. Similarly the equivalent stresses for experimental and finite element analysis for different acceleration loads are tabulated in the table 10. The comparison of experimental and FEA in table 10 shows 6$7 \%$ of average variation in the results of equivalent stresses in each axis. The maximum equivalent stresses in each axis are obtained for a load of $40 \mathrm{~g}$.

\section{CONCLUSION}

From the static analysis performed on the battery tray in 3 axes(x,y \&z respectively) the results of deformations and stresses are obtained for different ' $\mathrm{g}$ ' loads in each axis. The maximum deformation along $\mathrm{x}$-axis is $0.0434 \mathrm{~mm}$, along $\mathrm{y}$ axis is $0.10151 \mathrm{~mm}$ and along $\mathrm{z}$-axis its $0.41731 \mathrm{~mm}$ at a load of $40 \mathrm{~g}$. All the deformations are in safe limits. The modal analysis is performed on the battery tray by setting the number of mode shapes as 10 which gave the first natural frequency is $220.51 \mathrm{~Hz}$ and the tenth natural frequency is $664.3 \mathrm{~Hz}$. The harmonic analysis is performed for a frequency range of 0 to $680 \mathrm{~Hz}$ for the entire structure and at different points of the structure which shows the frequency response of the tray and at different parts of the tray. The maximum amplitude in is obtained at $650 \mathrm{~Hz}$ in $\mathrm{x}$-axis, at $450 \mathrm{~Hz}$ in $\mathrm{y}$-axis and at $220 \mathrm{~Hz}$ in z-axis. All the values are in safe limits. The FEAl analysis results are 5 to $7 \%$ over estimated when compared to experimental results, which is better than underestimation. This is due to the constant acceleration loading on the structure of the tray in simulation. In actual experimental condition there will definitely be power variations which may not constantly give the produce the same acceleration while the shock test is being performed which in turn varies the results. 


\section{REFERENCES}

[1]. Vasilopoulosa A.A and Beskos D.E. Seismic design of plane steel frames using advanced methods of analysis, Soil Dynamics and Earthquake Engineering, 27, (2007): pp 189. [2]. Mazzillia Carlos E.N., Sanchesa César T., et al. Nonlinear modal analysis for beams subjected to axial loads, International Journal of Non-Linear Mechanics, 43, (2008): pp. 551-561

[3]. Maurinia C., Porfirib M. and Pougeta J. Numerical methods for modal analysis of stepped piezoelectric beams, Journal of Sound and Vibration, 298, (2006): pp 918-933

[4]. Yooa Hong Hee, Chob Jung Eun, and Chungc Jintai. Modal analysis and shape optimization of rotating cantilever beams, Journal of Sound and Vibration, 290, (2006): pp. 223-241

[5]. Krawczuk M, Ostachowicz W. and Zak A. Modal analysis of cracked, unidirectional composite beam, Composites Part B: Engineering, 28,(1997): pp. 641-650

[6]. Chana Siu Lai. Vibration and modal analysis of steel frames with semi-rigid connections, Engineering Structures, 16, (2003): pp. 25-31

[7]. Gao Wei. Interval natural frequency and mode shape analysis for truss structures with interval parameters, Finite Elements in Analysis and Design, 42, (2006): pp. 471-477

[8]. Xu Y. L., and Zhang W. S. Modal analysis and seismic response of steel frames with connection dampers, Engineering Structures, ( 2001): pp. 385-396

[9]. Paz Mario. Structural Dynamics (Theory and Computation). Delhi: CBS Publishers \& Distributors, 1987.

[10]. Chopra Anil K. Dynamics of Structures (Theory and Applications of Earthquake Engineering). Delhi: Dorling Kindersley Pvt. Ltd., 2007

[11]. Allemang, R.J. 1984: Experimental Modal Analysis Bibliography. Proceedings of the $2^{\text {nd }}$ International Modal Analysis Conference, Orlando, Florida, pp.1085-1097

[12]. Brown, D.L.2000: Structural dynamics/modal analysis, Sound and Vibration, 34(1), pp. 6-9.

[13]. O. C. Zienkiewicz and R. L. Taylor (1991) The Finite ElementMethod, 4th edn, Vol. 2, London: McGraw-Hill.

\section{BIOGRAPHIES}

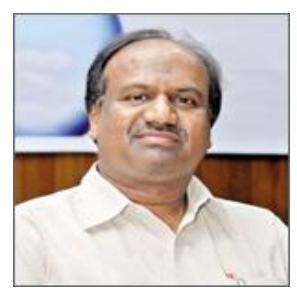

Dr. P. Ravinder Reddy was born on August $12^{\text {th }} 1965$, graduated in B.Tech Mechanical Engineering from Kakatiya University (1987) Warangal, M.E Engineering Design from PSG college of Technology, Coimbatore (1991) and Ph.D from Osmania University in 2001. He has 26 years of Teaching, Industrial and Research experience. He published over 205 technical and research papers in various international and national journals and conferences. He has guided $11 \mathrm{Ph} . \mathrm{D}$ scholars so far. As a facilitator for the learning process organized 27 STTPs/Workshops /FDPs /SDPs, 2 international conferences beneficial to Faculty, Researchers and Industry and delivered 105 keynote and invited talks. Was a chief and principal investigator for 17 research and 27 industrial consultancy projects sponsored by AICTE, UGC, NSTL, DRDL, BHEL, RR Industries,
ICOMM Tele services and ACD communications. He is a recipient of Raja Rambapu Patil National award for promising Engineering Teacher by ISTE for the year 2000 in recognition of his outstanding contribution in the area of Engineering and Technology, Excellence "A" Grade awarded by AICTE monitoring committee (2003) for the MODROB project sponsored by AICTE, "Engineer of the year Award-2004" for his outstanding contribution in Academics and research by the Govt. of Andhra Pradesh and Institution of Engineers (India), AP State Centre on 15th September 2004 on the occasion of 37th Engineer's Day, Best Technical Paper Award in the year Dec. 2008 in Industrial Application titled "Online quality monitoring welding \&weld upset in resistance projection welding process", in Journal of Non-Destructive Testing \&Evaluation, the official journal of ISNT during the year 2007 by National Governing Council of Indian Society for Non Destructive Testing

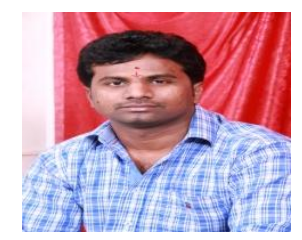

P. Shashikanth Reddy was born on August 12th 1986, graduated in B.E Mechanical Engineering from CBIT affiliated Osmania University in the year 2007 and M.S in Industrial and Systems Engineering from Northern Illinois University, DeKalb II in Dec.2009. Worked in Ford Motors Michigan and currently working in concurrent analysis pvt ltd. Published over 5 papers in international journals and conferences. The present work includes the Finite element analysis, Integrated Product and Process Design, Occupational Ergonomics, Advanced Product and linear programming network flows, Human factors engineering and six sigma performance excellences.

K.Vineeth Kumar Reddy was graduated in B.Tech Mechanical Engineering and Post graduation in M.E CAD/CAM from CBIT, affiliated to Osmania University. 